\title{
Ethnic Diversity in the Socio-Cultural Dynamics: Russia's Experience
}

\author{
Elena A. Erokhina* \\ Institute of Philosophy and Law of SB RAS \\ 8 Nikolaev Str., Novosibirsk, 630090, Russia
}

Received 08.10.2014, received in revised form 11.11.2014, accepted 10.03.2015

The article discusses the integration-fragmenting role of ethnic diversity in the development of Russian society (the post-Soviet period). As a theoretical model for research we propose the wave model of a dynamic process that explains its development in the logic of the alternation of two phases of one cycle, which is started by the introduction and then is accompanied by the subsequent distribution of a socio-cultural innovation. The article concludes that the processes of ethnic convergence and segregation are part of social and cultural transformation of society.

Keywords: ethnic diversity, socio-cultural dynamics, social and cultural transformation, variability and stability, integration and fragmentation.

Article was written with the support of the research project RFH "Ethnosocial Processes and Ethnonational Politics in Siberia” (№ 13-03-00417).

Research area: philosophy.

Russia is an integral part of the modern world, where the problem of ethnic diversity is relevant in theoretical and practical terms. Despite the unifying effects of globalization, overcoming national barriers, erasing of cultural differences, increasing interdependence of countries, peoples and civilizations, ethnic differences do not disappear. On the contrary, the development of globalization entails the amplification of ethnic diversity.

Meanwhile, the growth of ethnic diversity in the era of globalization is not an exceptional event, if we look at the historical process. For example, throughout the twentieth century processes of ethnic mobilization, enhancing the degree of ethnic diversity, twice went to the peak of activity: the first time after World War I, the finale of which coincided with the collapse of empires and the emergence of new nation states in Europe, the second time after the end of World War II, one of which resulted in the end of political colonialism.

As a part of sociodynamic processes, ethnic diversity is influenced by social and cultural transformation and renewal of its stable and volatile forms. Volatile forms of social and cultural transformation include economic models (pre-industrial, agro-industrial, industrial), ways of legitimizing of political power (dynasty-monarchic, national-citizenship),

(C) Siberian Federal University. All rights reserved

* Corresponding author E-mail address: leroh@mail.ru 
types of demographic reproduction (advanced, simple, depopulation), lifestyles (rural, urban), behavioral models (traditional, rational), types of collective memory (oral, written, printed).

Stable forms of social and cultural transformation include convergence and isolation of social, including ethnic, groups, alternating activity of dominant and nondominant communities, strengthening of either solidary or competitive forms of social, including interethnic, relationships, cultural unification and growth of the mosaicity. Being dependent on the process of social and cultural transformation in the stable aspect, ethnic diversity plays a fragmenting-integration role in the development of a particular society. Alternation of integration and fragmentation component of dynamic process and the appropriate role of ethnic diversity allow to put the question of the significance of this phenomenon in the social and cultural transformation. The mechanism of the transition from one state to another can be described by the wave of two-phase models, and socio-cultural dynamics of interrelated concepts: integration, fragmentation, resource, innovation.

The wave model is widely used to explain the dynamics of the oscillation cycle of economic conditions (K. Zhugliar, S. Kuznets, N. Kondratiev). In the post-Soviet period it was applied in the studies of social and cultural dynamics of semiotic systems [Lotman] and political institutions [Pantin, Lapkin].

Integration is a state of socio-cultural system in which it acquires new qualities because of the connection of its various components. The concept of fragmentation refers to the process of social and cultural fragmentation of the whole into parts, each of which can be a new kernel of integrity under certain conditions.

Resource is commonly referred to as a means for using certain actions to get the desired result. The characteristic of a resource is that it can be used for achieving certain objectives set by a person. As a rule, access to resources offers the right of membership in a group, which controls resource allocation. If we consider a social and cultural innovation as a resource, which is under implementation becomes a competitive advantage and object of social competition, including ethnic, groups, then it logically entails the high status of the innovation in this period. With the spread of innovations outside the group, which controls access to its use, the status of the innovation as such falls. A striking example is the use of cellular communication in the post-Soviet period: the cell phone within a decade from being a prestigious consumption item turned into a regular means of communication.

In this context, the loss of "overvalueness" of the novelty as long as it ceases to be an innovation becomes understandable. If all segments of the society have equal open access to any innovative resources, therefore, it makes no sense to erect barriers and to issue permits for the "newcomers" of the group, which acted as a novelty spreading mechanism during the introduction period. At the stage of dissemination of innovations the border between the once privileged group, on the one hand, and society, on the other hand, becomes permeable, and it eliminates the need to restrict access of new members to the prestigious group. The ability to leverage the competitive advantages is open to all sectors of society. The more widely a particular innovation distributed, the less we can talk about it as an innovation. Actually, the massive use of an innovation means its end as an innovation. In addition, since then being a member of the group, which controls access to it, stops being an indicator of social prestige.

The wave model explains the dynamic process in the logic of the phase rotation of one cycle. The phase of "chaos" is associated with innovation and adversarial accompanied by increased individual and collective actors in the 
competition for access to its use. The phase of "order" reflects the penetration of innovations in all structures of society, from the most prestigious to the most marginalized strata, and its transformation into a medium of exchange or as a gift, and if we talk increasingly, into a tool of social cooperation. The more distributed in different sectors of society an innovation becomes, the more aligned competitive abilities of various groups within society become. This creates preconditions for strengthening competitiveness when introducing next innovations. Broad access to resources, including technology, infrastructure, institutional, cultural innovation, not only helps to reduce social barriers and cultural restrictions. No less important is the fact that it allows you to align the controversial possibility of different groups in society to bring together social and structural parameters of the dominant and non-dominant communities within a society. This creates the conditions for a new round of competition and, therefore, to start a new cycle. These considerations are fully applicable to the analysis of changes in the status of an ethnic group in an environment where it is exposed to the influence of socio-cultural dynamics, stimulates the growth or reduction of its population, or the separation of convergence with other groups, simplification or complication of the ethnic structure of the whole society.

According to findings in natural sciences, in particular studies of I. Prigozhin and I. Stengers in thermodynamics, systems behave differently in an evolutionary phase of development, and at the time of the "jump" of qualitative transition [Prigozhin, Stengers]. This fact was taken into account when creating models of socio-cultural dynamics. The greatest interest in this regard is the model of "explosion" proposed by Yu. M. Lotman in the study of social and cultural dynamics of Russian culture. In the paper "Culture and Explosion", he identified patterns of development of a semiotic system at the time of the "explosion" and during the process of stabilization, which goes after it.

According to Yu. M. Lotman, dynamic processes built as variations between the states of explosion ("chaos") and the subsequent self-organization ("order "). The cause of the explosion is a complex interaction of internal and external causes, but it is always the result of the birth of something new, a "third" one, that is neither purely internal or purely external. In certain circumstances phenomena, generated by the explosion, for example if they are a new generation of innovation, can play a role of a source of subsequent wave oscillations.

The metaphor of the explosion helps to understand the dialectics of the destruction of the old order, ensuring the integrity of the system and the emergence of a new order, which can be both more and less complicated compared to the previous order. Formation of the new order is difficult to adapt, which dictates the need to adjust the goals and objectives of innovation needs and the needs of society.

The concept of resource is broader than the concept of innovation. Innovation is defined as a sociocultural innovation, the result of a borrowing or invention, initially perceived as an ambivalent novelty and then subsequently denied or accepted by society as a norm. The concept of innovation responding to the needs is related to the "top" of the Maslow's hierarchy of needs. Not only an innovation can be a resource, but also the means without which reproduction and self-preservation are impossible, for example, habitat (land and ecological niche), which are connected with their own way of life of the ethnic group.

The explosion is not a one-time transition to another, more perfect quality. Rather, it is the moment of transition from the integral unity of the system to differentiate it from a holistic interconnectedness of all its structures to their 
fragmentation. With regard to the strata and groups within society, including ethno-cultural and ethno-confessional communities, it is appropriate to speak of isolation, strengthening competition in the battle for competitive advantage, complicating the ethnic mosaic. Just at the time of exhaustion of the explosive effect a new order starts to emerge. It is accompanied by a rapprochement, a focus on inter-ethnic cooperation, unification of forms of expression of ethnicity.

The phase of chaos ("change") begins at the moment of intense innovation, fragments society into groups, forced to compete for access to private innovations, which become important resources. Terms of use of resources are determined by the status of ethnic groups in society, and within the group - by the proximity or remoteness of the members of the group to its core part. The core / peripheral position depends on the position of the individual in the group, which, in turn, is influenced by two factors: the identity and recognition. We can assume that the proximity to the core part depends on the recognition of the individual as a member of the "inside" and "outside" community. Accordingly, if the personal identity becomes subjected to questioning by the group, it would mean that the individual gets a peripheral position in the community. If the identity is rejected by the group, it blocks access to the group for the individual, and, therefore, excludes him (her) from participation in the distribution of the resources. It is important to bear in mind that in the phase of the explosive dynamics there is a correction of membership rules under the influence of situational circumstances, access to the group becomes restricted, requirements for membership increase, and boundaries of groups become more stringent. This contributes to the isolation of the groups and the formation of rigid boundaries between them. The basic need of people during the stage of change is the need for survival. The need for development arises in the second phase of the cycle, in the phase of stability ("order").

After the exhaustion of the explosive effect the phase of "order" comes along with the establishment of a new relationship between the social fragments produced by the explosion. The new procedure may resemble the old one in terms of the individual, but it will not be a repetition of the old order, since the elements of the assembly will be different in quality compared to the former one. The assembly will require additions of competitive relations of cooperation. The quality of these relations will be exposed to the "resource" estimation, therefore, the more beneficial the inter-ethnic cooperation of the parties of the interaction becomes, the more likely it will strengthen the solidarity of interactions. The higher the rate of diffusion of innovations of the most prestigious groups in the mass circulation, the greater becomes the group of innovations' translators. The increasing of the number of its representatives is achieved by the recruitment of fragmented communities, which begin to realize that they belong not only to the group structure, but also to the society as a whole.

Multiple identities make the boundaries between groups more permeable, and the rules of membership in the group become less stringent. It eliminates the need to expose identity to testing for compliance with the representations of the group. Rules of membership in the group are no longer dependent on situational factors, access to the group becomes more open, and its borders start to move. It contributes, for example, to the convergence of the ethnic group with more ethnic communities, and ultimately creates conditions for the formation of ethnic communities. Ultimately, it is the stable phase, where the need for development of most members of society can be implemented. 
This creates prerequisites for integration, leveling possibilities of representatives of different groups in the competition, as indicated, for example, by L.M. Drobizheva [Drobizheva].

It is worth noting the fact that she was the first researcher to propose a methodology of system research of ethnic phenomena simultaneously in two perspectives: system-structural and phenomenological. This experiment, carried out in relation to the study of ethno-social situation in post-Soviet Russia, has been consolidated in the framework of an average level, which is known as poly-paradigmatic concept of ethnicity. It had a huge impact on the post-Soviet ethnosociology, including the current study. For example, the concept of competition, cooperation and comparability (in the context of inter-ethnic cooperation reflexivity), which became the key to describe the dynamic model, were borrowed from the model by L.M. Drobizheva.

In order to justify the lawfulness of the use of the linear model of socio-philosophical study of the role of ethnic diversity, we try to examine ethnic diversity in two projections - in objectactivity and subject-activity. Here we can resort to the help, for example, of the results of the last Soviet census in 1989, and two Russian Census Census 2002 and Census 2010 as well as the conclusions made on their basis, with respect to ethnic and linguistic dynamics of the peoples of Russia in the post-Soviet period.

The number of peoples, as it is claimed, for example, by D.D. Bogoiavlenskii, who analyzed the ethnic section of the census, depends on two factors. The first factor can be conventionally called a nomenclature or a "list" [Bogoiavlenskii]. The number of peoples taken into account in the census depends on the lists that are made up by the state statistical bodies in accordance with recommendations of ethnographers. A certain number of ethnic groups is formed from a long list of ethnonyms and self-names. It is not surprising that the number of people from the census to census changes and the nomenclature lists are not the same.

The attitude of the authorities to the nomenclature of the census, as was shown in the study by B. Anderson, is characterized by the requirement of unambiguity. "The census idea is that every person would be enumerated and would get one - and the only one absolutely clear position. And no fractions" [Anderson]. The choice of an individual of their ethnic affiliation from the nomenclature list may be dictated by his (her) strategy of adaptation. This, for example, was shown by two Russian census data, which indicated that the Shor group of the Khakases allocated itself as an independent group with the status of indigenous peoples. The Altai ethnic groups - the Chelkans, Kumandins, Tubalars and Telengits have also put themselves separately. What is now the status of these groups: the status of independent ethnic or sub-ethnic groups? It is a very interesting question, given that in 2002 changes in the procedure for the census were introduced.

Since 2002 census following V.A. Tishkov and his colleagues 's initiative from the Institute of Ethnology and Anthropology of the Russian Academy of Sciences a new factor came to the fore front: the factor affecting the number of people and the number of individual ethnic groups. This factor is called ethnic identity. The final lists of peoples are subjected to the adjustment on the basis of self-determination. The principle of Russian census gives a visual representation of what V.A. Tishkov calls "ethnic processness" [Tishkov].

Census 2002 introduced two accounting principles: according to the first one they record the statistics of "separate" ethnic groups, according to the second one - the statistics of the "included" ethnic groups. It was decided before the 2010 census to highlight "included" ethnic groups 
together with the "separate" ones. The census of 1989 enlisted 128 peoples. According to the two Russian census, based on counting the number of "individual" and "included" groups, in 2002 there were 142 "individual" and 40 "included" peoples (total 182 "separate" peoples), in 2010 145 "individual" and 48 "included" peoples (of total 193 "separate" peoples) [Bogoiavlenskii]. The 2002 census showed an increase in ethnic diversity in comparison with the Soviet period. However, the results of the Census 2010 suggest a stabilization of this indicator in the 2000s.

Analyzing the causes of accounting of some ethnic groups simultaneously in two ("separate" and "included") lists, D.D. Bogoiavlenskii comes to some interesting observations. In particular, he drew attention to the "jump" of the three peoples - Telengits, Chelkans and Tubalars - from "separate" peoples in 2002 to the group of "included" in 2010. All the three peoples, as well as Teleuts and Kumandins recorded in Census 1989, entered the "List of Indigenous Peoples of Siberia, the North and the Far East", while the Altai people in this list were not included. Bogoiavlenskii asks a question: "Why now they are deprived of being "separate"? Whereas, for example, Teleuts and Kumandins preserved their "private" status. And quite rightly suggests that without these three peoples as "included" in the Altai people in 2010 census the population of the titular ethnic group in the Republic of Altai would be significantly lower [Bogoiavlenskii]. The prospect of such a situation, according to the Altai people and representatives of related ethnic groups, could jeopardize the legitimacy of the republican status of a subject of the Russian Federation, which is an asset for all the peoples of the Altai Republic. This assumption was confirmed during the field work under the grant of RNGF "Actual problems of interethnic relations and national policy in the regions of Siberia in the estimates of the mass consciousness" in the Altai Republic in 2014.

In a study of A.P. Chemchieva the problem of dual identity of representatives of Altai sub-ethnoses was considered in the context of ethno-political processes that determine their mobilization as the title and the indigenous peoples [Chemchieva]. In 1990s - early 2000s the identification as indigenous peoples was a prestigious innovation and had certain advantages afforded to those who were added to this category. This was true in terms of certain social benefits, benefits to use the land for traditional economic activities in the private-proprietary, and on a collective basis, the most appropriate value system of the indigenous population. The same applies to the ability to create a community and expect government support in the creation of territories of traditional nature. For the most Altai, it is worth noting that this group was also on the rise under the influence of the sovereignty and status of the Gorno-Altai Autonomous Region up to the Republican.

The researcher warns of the approach to the issue of self-determination of sub-ethnoses of the Altai people from a position of focusing on the separation process [Chemchieva]. On the basis of her sociological research 2004 in her monograph (4 years after the Chelkans, Kumandins, Tubalars and Teleuts were put on the "List of Indigenous Peoples of Siberia, the North and the Far East") it was concluded that about $49 \%$ Altai people had dual ethnic identity [Chemchieva]. Some of them equally felt being a representative of the Altai and a related (Chelkan, Telengit Kumandin, Tubalars, Teleut) group. Among the representatives of the northern Altai sub-ethnoses the highest figure of mono-ethnicity was only in Kumandins (36.1 \%). Among Chelkans and Tubalars the proportion of persons varies, according to her research, 20 to $25 \%$. The share of persons with a double (the Altay and "own") identity among Tubalars and 
Chelkans is more than a half: Tubalars $-60 \%$ Chelkans $-58 \%$. The lowest rate in this indicator is for Kumandins - 49,9\% [Chemchieva].

The subject-activity perspective allows to make an assumption that there are two strategies of ethnic identity in the transition from a crisis phase to the stabilization phase. The first strategy can be conditionally called complementary. The complementary strategy suggests a possibility of a broad (but not unlimited) range of loyalty from smaller ones to larger ones (Tubalars, Altaians, Turks), the permeability of borders between the two groups, the ability to use the whole range of types of self-determination. The second strategy can be called "alternative". It involves a limited number of loyalties, a unique choice of ethnic identity, establishing rigid boundaries of both: by the group itself and by other groups in society.

The more powerful was the "explosion" that led to fragmentation the more stringent requirements for its members are applied by the group, which selected the "alternative" strategy. According to the research of identity of the participants of local wars (the Balkans, the Caucasus, Ukraine), the transition to the mode of hard, sometimes armed opposition of the parties of interethnic interaction requires that a person having dual identities, should select one of the two possible loyalties. The one which is "right" for the reference group to which he (she) belongs. To keep the dual identity in such cases can only be possible through leaving the area of the local conflict.

Now we shall return to the census. It would be logical to assume a direct connection between the multiplication of ethnic diversity and complexity of the linguistic structure of society. However, when analyzing the data of the Census 2010 in the context of a comparison with the results of the last Soviet census of 1989, this correlation is not observed. This conclusion is based on the analysis of the language of self-determination.
Thus, in the report of Rosstat on the basis of the 2010 Census indicate that in the period from the 1989 census, the population changed in relation to self-determination of the native language. In 14 nations (except Russian) increased the proportion of persons named native Russian. The highest growth rates were observed among the Kazakhs, whose share of the persons named Russian as their native language increased by 2.4 times. Russian language is the native majority of the Belarusians ( $83 \%$ ) and Ukrainians ( $76 \%$ ). This is not surprising, given the predominantly dispersed settlement patterns of representatives of these ethnic groups in Russia, and stay out of space the language environment in which they dominated as a means of communication. However, the share of persons for whom the Russian language is native also increased among the peoples of Russia, which in its territory have national and state education, supporting the titular languages. For example, the Russian language is native for about a third of Udmurtians and Mordovians, from 21 to $29 \%$ of the Chuvash, Mari, Buryat and Tatar. This idea of speaking the Russian language and the national language of these peoples can give the following ratio: $98.6 \%$ against $68.9 \%$ in the Chuvash, $98.7 \%$ to $67.4 \%$ in the Maris, $99.2 \%$ to 45.4 Buryat $\%, 97.8 \%$ to $69 \%$ of the Tatars [on the demographic and socio-economic characteristics of the population]. Comparative analysis of the data from the two censuses (2002 census question on mother tongue was not contained) indicates, rather, the harmonization of the language space under the influence of the Russian language.

The proposed two-phase wave model helps to explain the experience of post-Soviet national and ethno-linguistic policy, reproducing in stable waveforms through the "fragmentation integration". Ultimately it can be schematically represented as a succession of strengthening the position of the official languages of the Russian 
Federation: the titular languages and Russian. This standard language of communication in the post-Soviet period has become bilingual, Russian-national bilingualism - a product of the Soviet modernization inherited Russian society.

In object-activity-term separation and convergence of ethnic groups under the influence of innovation and their subsequent distribution looks like a change of phase of the cycle, in which the stable interlace of sequence of multiplication and stabilization of the number of ethnic groups is reproduced, the activity of non-dominant oscillation (titular and small) groups and the dominant Russian majority, the expansion of the communication space of minority languages and strengthening of cultural unification under the influence of the language of the dominant culture. In the phase of "chaos" different groups in society are to varying degrees ready to accept innovation as a value, and those segments of society who have experienced a decrease in the status of the disappearance of the "old" order, tend to view them as anti-values. The explosion of the situation is fragmented society through acceptance / denial of new values, and the attitude towards them is dependent on changes in the social status of the subject.

The situation changes in the phase of stabilization: the more innovation has penetrated into the society, the more people are members of the community who have an opportunity and ability to put the innovation at the service of themselves and society. The wider is the group of translators of innovations, the more likely a society reaches a consensus on the adoption of new values. If consensus is accompanied by a statement of the new rules of life, recognized as legitimate by all members of society, and the structural changes are under the control of society, we can talk about resolving the crisis.

An example of such an innovation, which had a marked influence on the development of
Russian society, was the sovereignization of 1990s. Sovereignization can be understood as ethno-political mobilization, which took place under the slogan of national culture revival and rehabilitation of political functions of national languages. One of the main objectives was to increase the sovereignty of the status and scope of authority of national-territorial entities of the Russian Federation.

The attitude to sovereignty of the 1990s even today remains controversial. Many Russians, especially in the national republics of the Russian Federation, recall the "parade of sovereignties" negatively. This category negatively reacted to the politicization of the language problem. The rapid disintegration of the USSR gave grounds for the concern. The changing nature of the asymmetry in favor of national cultures and to the detriment of the Russian-speaking Soviet / all-Russian culture are most strongly fragmented regional communities, where there was a high proportion of non-Russian population (Republic of Tatarstan, the Republic of Sakha (Yakutia)). In a number of republics there were numerically dominant titular nations, there was an outflow of the Russian-speaking population (Tuva Republic, Republics of the North Caucasus).

As long as the ethnic conflicts on the territory of the Russian Federation more or less were settled and Russia acquired some attractiveness for immigrants from neighboring countries, public attitudes toward sovereignty "softened". It was obviously under the influence of the fact that it gave certain results and was no longer perceived as an innovation that causes the contradictory attitude of society. Those nationalterritorial entities that work to increase their status in the new political-administrative and territorial structure of the Russian Federation, in part achieved their goal. The status of most of them was promoted to the level of subjects of the Russian Federation. Along with the wave of 
ethnic and political revival there were created institutional and social structures that took the mission of preserving and developing their native language and culture. National-cultural autonomies and national public associations, tribal communities, councils of elders delivery of specific ethnic groups were established, standards of a regional component in the educational system of the RF subjects were introduced.

Ethnic mobilization of titular ethnic groups caused consolidation processes among Russians. Strengthening ethnic consolidation is, contrary to popular belief, the opposing element for the "chaos" of "order", which is based on the premise of ethnic integration. Today, the concept of sovereignty has disappeared from the political vocabulary. Sovereignization very rightly can be considered as an innovation that has become an additional resource for the representatives of the titular population benefiting from the advantage of bilingualism and reliance on kinship and connection in a situation of competition with the Russian population. However, objectivity demands to recognize that by rising the status of national-territorial entities to the level of the subjects of the Russian Federation brought some benefits for the entire population that fought for the new status of regional communities. When the "parade of sovereignties" was replaced by "strengthening of the vertical of power", which was followed by the trend in the enlarged regions, few subjects of the federation supported the line of the federal government and agreed to donate an independent status. For example, all the Turkic republics of southern Siberia rejected such a scenario. This part of the Russian population of the relevant subjects of the Russian Federation, the majority in two of the three national republics (Khakasia, Altai and Tuva), favor maintaining the status of a subject of the Russian Federation not less active than the titular population.
In the 2000s the national republics of the Russian Federation formed the preconditions for the shaping regional civil identity (tatarstans, yakutians, and yugorchanins). An interesting example is the allocation of sovereignty from the Tyumen region of Khanty-Mansiysk autonomous districtundertheGovernorAlexanderPhilippenko. The share of the title population in the ethnic structure of the subject of the Russian Federation in the post-Soviet period did not exceed $2 \%$ of Khanty $-1.2 \%$, Mansi $-0.7 \%$. Nevertheless, the idea of patriotism of Ugra was well received not only by indigenous northern ethnic groups, but also by the Russian population.

Sovereignty has given positive results in some regions. However, experience shows that sovereignty as one innovation, no matter how effective it is as a social impulse, cannot lead to the prosperity of society, if it is implemented individually, without regard to others. Therefore, we have the experience of sovereignty by Tatarstan and Ugra, economically successful regions, but there is also the experience of sovereignty of the North Caucasus, which was quite different. In this test, there is an armed conflict and a return to the archaic model, not as a model of adaptation, but as a strategy of existence in a shattered modernization.

Attempted analysis allowed to identify the signsandindicators offragmentation-integration of society on ethnic basis. Objective evidence of fragmentation of society is the multiplication of ethnic diversity, which is accompanied by processes of ethnic differentiation, separation, isolation. The growth of ethnic diversity, recorded when comparing the results of the Census 1989 and 2002 shows the fragmentation of the Russian society in the phase of "chaos" of the 1990s. Subjective measures of fragmentation began to activate titular ethnic groups and strengthen the dominant national bilingualism [Sagitova]. 
Russian society enters a phase of integration in the 2000s. Objective evidence of this phase can be traced in the stabilization of ethnic groups within a particular society. Stabilization was accompanied by processes of ethnic consolidation, inter-ethnic integration and rapprochement of ethnic groups. The census of 2010 showed the preservation of ethnic diversity at the level of 2002, with a slight increase in the allocated ethnic groups and expanding the proportion of individuals who refused to ethnic self-determination. Some people, who were rewritten as separate in 2002, in 2010 and were rewritten as individual and as included. In our own field experience the author traveled to Telengit village in the Kosh-Agach district of the Altai Republic and interviewed more than 100 of their inhabitants can confirm the existence of a double ethnic identity. The Altai Telengits who recognize themselves as part of the Altai nation and independent people simultaneously.

Our observation is confirmed by studies of other social scholars. In particular, the studies of A.P. Chemchieva 2004 (for example, the Altai and related ethnic groups in the Altai Republic) reflected the growth of a significant proportion of people with a dual ethnic identity complementary to combine ethnic and sub-ethnic identity in the structure of society [Chemchieva]. The approximation of unrelated ethnic groups suggests the establishment of regional ethnic communities in the national-territorial subjects of the Russian Federation, in particular, the Turkic republics of southern Siberia [Erokhina].

The wave model explaining dynamic processes in the logic of the alternation of the two phases of the cycle, the development of which started the implementation and subsequent spread of social and cultural innovation, helps to explain the sequence of alternations of multiplication and stabilization of the number of ethnic groups, the oscillation of non-dominant (titular and small) groups or the dominant Russian majority activity, the pendulum movement of the expansion of the communication space of minority languages to its subsequent reduction under the influence of cultural unification and strengthening of Russian influence. In this logic integration and fragmenting role of ethnic diversity in the development of a particular society becomes apparent.

As a factor which dependent on the sociocultural changes, ethnic diversity affects the development of a particular society in aspects of the reproduction of stable, inversion forms of its socio-cultural dinamics. Description of the theoretical models of this process contributes to the understanding of the cyclical nature of social and cultural transformations. The depth of this understanding is a prerequisite for managing inter-ethnic relations and the authorities, and, not least, by the subjects of the ethno-social and ethno-cultural relations.

\section{References}

1. Anderson B. Voobrazhaemye soobshchestva: Razmyshleniia ob istokakh i rasprostranenii natsionalizma [Imagined Communities: Reflections on the Origin and Spread of Nationalism]. Moscow: Publishing House "Kanon-press-tse", 2001.

2. Bogoiavlenskii D.D. Perepis' 2010: etnicheskii srez [2010 Census: Ethnic Section] // Demoscope Weekly. № 531-532. November 2012. Available at http//demoscope.ru/weekly/2012/0531/ index.php

3. Drobizheva L.M. Mezhetnicheskie otnosheniia // Etnosotsiologiia [Interethnic relations // Ethnosociology] Moscow: Aspect Press, 1998. Pp 184-198. 
4. Erokhina E.A. Etnicheskie granitsy v mezhetnicheskom soobshchestve // Gumanitarnye nauki v Sibiri [Ethnic boundaries in inter-ethnic community // Humanities in Siberia]. 2007. № 3. Pp. 100104.

5. Lapkin V.V. Tsikly, ritmy, volny: problema modelirovaniia politicheskogo razvitiia [Cycles, rhythms, waves: the problem of modeling political development] // Polis. 2002. № 4. Pp. 26-31.

6. Lotman Yu.M. Kul'tura i vzryv [Culture and explosion] // Semiosphere. Saint-Petersburg: 2000. Pp. 14-154.

7. O demograficheskikh i sotsial'no-ekonomicheskikh kharakteristikakh naseleniia otdel'nykh natsional'nostei Rossiiskoi Federatsii (po itogam Vserossiiskoi perepisi naseleniia 2010 goda) // Itogi Vserossiiskoi perepisi naseleniia $2010 \mathrm{v}$ otnoshenii demograficheskikh i sotsial'no-ekonomicheskikh kharakteristik otdel'nykh natsional'nostei [On the demographic and socio-economic characteristics of the population by nationality of the Russian Federation (based on National Population Census 2010) // The results of the National Population Census 2010 in relation to demographic and socioeconomic characteristics of individual nationalities]. Available at http://www.gks.ru/free_doc/new_ site/perepis2010/croc/Documents/Materials/doklad2.docx

8. Pantin V.I. Vozmozhnosti tsiklicheski-volnovogo podkhoda k analizu politicheskogo razvitiia [Cyclic-wave approach to the analysis of political development] // Polis. 2002. № 4. Pp. 19-25.

9. Prigozhin I., Stengers I. Poriadok iz khaosa. Novyi dialog cheloveka s prirodoi [Order out of chaos. The new dialogue between man and nature]. Moscow: Progress, 1986.

10. Sagitova L.V. Regional'naia identichnost': sotsial'nye determinanty $i$ konstruktivistskaia deiatel'nost' SMI (na primere Respubliki Tatarstan) [Regional identity: social determinants and constructivist media activities (in the case of the Republic of Tatarstan)] // EtnoZhurnal № 4 (October) 2003. Available at) http://www.ethnonet.ru/lib/1003-01.html

11. Tishkov V.A. Rekviem po etnosu: Issledovaniia po sotsial'no-kul'turnoi antropologii [Requiem for Ethnos: Studies in social and cultural anthropology]. Moscow: Nauka, 2003.

12. Chemchieva A.P. Altayskie subetnosy v poiskakh identichnosti [Altai sub-ethnic groups in search of identity]. Novosibirsk: Publishing House of the Institute of Archaeology and Ethnography, 2012. 


\section{Этническое многообразие}

\section{в социокультурной динамике: \\ опыт России}

\section{Е.А. Ерохина}

Институт философии и права СО РАН Россия, 630090, Новосибирск, ул. Николаева, 8

В статье рассматривается интеграционно-фрагментирующая роль этнического многообразия в развитии российского общества (постсоветский период). В качестве теоретической модели исследования предложена волновая модель динамического процесса, объясняющая его развитие в логике чередования двух фаз одного иикла, который запускается внедрением и сопровождается последующим распространением социокультурных инноваций. В статье сделан вывод о том, что процессы этнического сближения и обособления являются составной частью сочиокультурной трансформаџии общества.

Ключевые слова: этническое многообразие, сочиокультурная динамика, сочиокультурная трансформачия, изменчивость и устойчивость, интеграция и фрагментация.

Статья подготовлена в рамках научно-исследовательского проекта РГНФ “Этносоциальные процессы и этнонациональная политика в регионах Сибири” (№ 13-03-00417).

Научная спещиальность: 09.00.00 - философские науки. 